\title{
The Instruments to Reform the World System of Currencies: Internationalising the Currencies of the BRICS
}

Mikhail Zharikov

Doctor of Economics, Professor of the World Economy and World Finance Department, Financial University, Moscow, Russia

michaelzharikoff@gmail.com

http://orcid.org/0000-0002-2162-5056

Abstract

The general outcomes of this article come from a hypothesis that expanding the BRICS currencies in the contemporary World System of Currencies (WSC) is going to be a major driver of reinforcing financial stability and transforming the WSC by means of the internationalisation process as a result of direct international settlements as well as through purchasing them using currency vehicles at the national foreign exchange markets. As a result there emerges a need to analyse the BRICS currencies' circulation abroad, identifying the stages and directions of their internationalisation, considering the role they may play in the future development of the economies and near-by regions, their cooperation in mutual trade, investment flows, technology exchange, research and development, energy, financial stability and economic security. The article is especially timerelevant since the yuan is becoming a world reserve currency that may change the structure and the mechanism of the WSC.

Keywords: the currencies of the BRICS, currency internationalisation, financial globalisation, the reform of the International Financial Architecture, the World System of Currencies, the BRICS exchange rate regimes.

JEL Classification: F37

\section{The Currency Internationalisation Theory}

At the beginning of the 21st century, there appear certain changes in the views and ideas about the world economy and world economic relations. There are changes in the basis of their scientific and technological development. The globalisation process is being transformed. There emerges a new paradigm of social science. Multilateral initiatives of the emerging economies are becoming drivers of globalisation, and there arises a need to analyse, evaluate and forecast their role and future in the world economy (Kaufman, 2001). The paradigm of the existing world system of currencies (WSC) is undergoing a transformation process under the influence of many factors, including the internationalisation of some of the world's countries' currencies, especially the BRICS' currencies. Currency in- ternationalisation has become a crucial part of financial globalisation. The BRICS' currencies, first of all, the Chinese yuan, or Renminbi (RMB), are aggressively penetrating the world market and are being built into the WSC (Yu, 2014). The yuan has been included in international reserves, the SDR currency basket and international liquidity (Avdokušin \& Kovalenko, 2012).

New financial instruments are coming into being at the international financial markets. These new financial instruments formerly used to decrease the level of the currency risk. Now they cause systemic risk in the WSC which in the late 20th - early 21 st century has become an important factor for financial crises to emerge, spread and repeat. Financial disparities and distortions led to the global financial crisis of 2008-2010 and a systemic crisis of the WSC. The world financial and economic crisis 
destabilised the WSC as well as national systems of currencies in many countries of the world, which resulted in those currencies' devaluation and increased their volatility.

Due to financial globalisation, its development and intensification, the contagion effects started to spread via financial channels to hit many countries of the world (Schindler, 2009). This is because the countries of the world today are becoming more and more interconnected. And in case of a financial crisis in one country, there exists a strong possibility of its spreading over to other countries linked by a chain of international currency, international debt, international trade and other economic relations.

As world prices in the international trade are expressed in US dollars, this greatly affects the economic development of many countries, including the BRICS. For China, the world prices are critically important because it is a world factory and the largest exporter of goods as well as the greatest consumer of energy and other resources. India is a large importer of energy and exporter of goods and services with a high value added. Russia, Brazil and South Africa are one of the largest world exporters of raw materials, agricultural products and minerals. Therefore the instability of the WSC and world prices immediately affect the international competitiveness of the BRICS. For China and India, an increase in world raw materials' prices means more expensive imports, greater production costs, higher inflation rates and the devaluation of the yuan and rupee. In Russia, Brazil and South Africa growth in world prices of energy, agricultural products, minerals and other materials led to similar consequences. However, the three countries are less sensitive to these fluctuations because they are set off by export revenues of the extracting industries resulting in soaring government revenue in the form of taxes, customs duties and hard currency reserves. In contrast, China and India buying more expensive imports start to export their finished goods at higher prices, which is why their losses are significantly greater since their total exports are much larger than those of Brazil, Russia and South Africa. On the other hand, a drop in the world prices of raw materials and intermediate products reduces export revenues of the three countries, halts their economic growth, makes them increase internal prices and taxes to compensate budget losses and leads to inflation and the devaluation of the real, rouble and rand. Whereas China and India get profited from decreasing world commodity prices because by importing cheaper inputs they will produce less expensive finished goods which are more price-competitive. And when exporting the finished goods, the two countries will get more profits. However, such externalities may result in extreme long-term unsustainability of economic growth in the BRICS as a whole, as their development is going to be constantly dependent upon external factors which they cannot change or make adjustments for.

Hence the problem of trying to find ways and instruments to reduce foreign exchange risks is becoming more and acuter. Traditionally, these risks have been hedged by means of currency derivatives such as futures, forwards, etc. But the international foreign exchange market and the international derivatives' market are dominated by the dollar. And more than $90 \%$ of both markets' total turnover is of speculative nature meaning that these markets' transactions do not practically serve the interests of the real economy. The virtual character of the transactions leads to more frequent and deeper crises (Lane \& Milesi-Ferretti, 2011). Therefore the BRICS, besides being dependent upon world commodity prices, are vulnerable to the situation on the international foreign exchange market and the international derivatives' market. That means that to stabilize the commodity prices and the export revenues the BRICS need other approaches to dealing with the foreign currency risks.

One of such approaches may become the currency internationalisation which nowadays attracts much attention of many researchers both in Russia and elsewhere.

\section{The Currency Internationalisation Phenomenon}

The interest in the research on the currency internationalisation can be explained by the fact that it finds itself on the intersection of several scientific areas including world economics, international and national finance, international debt, currency circulation, and banking and stock exchange activities. The 
currency internationalisation issue has become acuter due to the world financial crisis of 2008-2010 when there were fears of the dollar crash or the dollar bankruptcy. Some economists made pessimistic scenarios as to the dollar's future status in the WSC (Wade, 2008).

At the present, among the BRICS' currencies, only the yuan and to some extent rupee have good chances of being internationalised (Kadayan, 2014). The real, rouble and rand, in their turn, may only claim for regional currency status within the respective integration agreements (Kasekende, Brixova \& Ndikumana, 2010). A major factor for their internationalisation or, better, regionalisation is the role the BRICS play in the global economy and in its certain areas. The currency regionalisation is part of the currency internationalisation. It stands on a lower level and is bounded to a certain territory.

By cooperating with China in the international and regional trade, investment, and foreign exchange transactions as well as by participating in the China-led financial institutions, Brazil, Russia, India and South Africa will be able to use their currencies more widely first at the regional level and then probably at the level of the global economy.

As a result of the yuan's vigorous rise, we expect transformations in the international financial architecture (IFA) and the WSC.

The contemporary WSC works on the basis of the agreements that were reached in Kingston, Jamaica, in 1976. These agreements ruled the free-floating exchange rate regime which since then brought about the ever increasing foreign exchange risk that started to seriously affect national currencies' stability. The world foreign exchange market became ungovernable, and the world prices began fluctuating very dramatically, destabilising the national systems of currencies in many sovereign states, especially the developing and emerging countries. The issue of international indebtedness has turned out to be very acute.

After decades of the existence of the system of fixed and free-floating exchange rates, the US dollar integrated into the WSC so deeply that it is almost impossible to imagine now that it may be pushed by some other currency. However, the discussions to find a substitute to the dollar become usually quite acute during world crises. The most serious ones occurred in the 1970s, late 1990s and at the end of the first decade of the $21^{\text {st }}$ century.

At first oil shocks of the 1970s and 80s led to the economic downturn in Western Europe and Japan as a result of a sharp rise in world oil prices and a drop in export competitiveness. Soaring world oil prices led to an increase in demand for the dollar because it is the currency in which all world commodity prices are quoted. Contrary to many expectations the situation eventually helped strengthen the dollar's exchange rate. And since more expensive oil brought more profit to the oil exporting countries, dollardenominated accounts spread outside the US all across the globe concentrating in the largest international financial centres, which helped the development of the Eurodollar market.

The Asian financial crisis of 1997-1998, in its turn, forced the emerging markets to take loans from the International Monetary Fund (IMF) and the World Bank, which again created additional demand for the dollar and once more reinforced its position and status in the WSC.

Finally, as a result of the world financial crisis of 2008-2010 the deficit of liquid assets in the international financial market allowed the US to expand the dollar supply which in the end again strengthened its role in the WSC.

Furthermore, to prevent a crisis from happening, each nation in the world accumulates reserve funds that are mainly denominated in dollars. The BRICS are the largest keepers of the official reserves in dollars among the developing countries. And since they are overwhelmingly export-oriented economies, they still receive dollars in exchange for their produce, which again stimulates the demand for the dollar and supports its exchange rate and the positions in the WSC. This helps draw a conclusion that each new world crisis that follows and the fast development of a few countries needing huge amounts of foreign capital and loans for further economic growth will result in the dollar's reinforced position in the WSC. Thus perhaps the only way to break through this vicious circle is, as is suggested by the author, a long-term evolutionary period of accumulating negative differences in the WSC. These differences are becoming acuter due to systemic violations of 
the international currency issuance rules by the US as the key world reserve currency sovereign. First, the US violated the principles of the Bretton Woods system, and later - those of the Kingston Agreement. The violations are expressed in the fact that the US allows inflation, devaluation, losing value against the gold, chronic deficit of the payment balance and current-account balance and a very big gap between the consumption and saving. The US finances its budget expenses at the expense of the dollar emission. The US has also accumulated the significant external debt (Goldberg \& Cédric, 2008).

The WSC's transformation may also happen as a result of a gradual increase in the BRICS currencies' use in international and regional settlements when there will come into being the factors and drivers that will allow driving the dollar away from its key position.

Further to the analysis of the special features of the WSC's development, we conclude that it changes approximately each $30-40$ years. The Jamaican monetary system is already more than forty years old. So, perhaps the new principles, goals, purposes and functions of the WSC which have been discussed during all the G20 summits starting from 2008 are a process of coming to a new international monetary agreement. It has not received a finished shape in the form of a common document yet, but it is quite probable that by the end of the second decade of the $21^{\text {st }}$ century there will have been created a new WSC under a new name in the contemporary world economy. Therefore, to take a respectable position in the new emerging WSC it is necessary to negotiate now the conditions under which various countries are going to participate in it. These conditions will have to be negotiated as part of the WSC's far-reaching reform (Jordà, Schularick \& Taylor, 2011).

Currently, the WSC's reform is about strengthening the IMF and the World Bank by means of increasing reserve funds, bilateral swap agreements between the biggest central banks and diversifying the credit instruments' portfolio in the international financial institutions (Griesgraber, 2009). However, there were no cardinal changes in the WSC since 2008, and the role of the developing countries in it remained practically the same because the ad- vanced countries block the possibilities of the former through the IMF by actively pushing through their interests in the IMF (Burlačkov, 2012).

Nevertheless, the BRICS continue their search for the ways of expanding their participation in the WSC's institutions. The essence of their approach is to set up extra financial institutions and funds (such as the BRICS Development Bank) and to diversify international liquidity by first of all including the yuan in the international reserves (Binder, 2013). Brazil, Russia, India and South Africa thanks to cooperation with China in the sphere of international trade, investment, monetary policy and participation in the financial institutions created by China will be able to more widely use their national currencies first at the regional level and then, probably at some future moment, at the level of the global economy (Butorina, 2011).

Extra financial institutions' goals include looking for the sectors of the world debt market where the IMF's and World Bank's presence is small in order not to stimulate the competition and destabilize the WSC. This means the inclusion of the BRICS' financial institutions into the existing WSC and the emerging world financial stability network.

\section{The Reform of WSC}

The IMF's reform is a far-reaching process which may involve the increase in the use of a few countries' currencies in the international transactions and settlements as a result of the currency internationalisation. The creation of a new WSC may be preceded by the establishment of a transitional one which will be based on a few currencies such as the dollar, the euro, yuan, pound sterling, yen and special drawing rights (SDR). This may result in diversifying the international liquidity and a reduction in monetary and financial risks. The new WSC may include the currencies of the BRICS that enjoy high economic growth, wide possibilities of providing loans to foreign nations, massive expansion of capital onto the foreign markets and technological and military supremacy compared to other countries. None of the BRICS has such excellent qualities in a total. Therefore they are not able to 
claim for hegemony in the world economy yet. This means that a deeper participation of the BRICS in the WSC today is only possible under the conditions of collectively making use of their specific competitive advantages.

The financial competitive advantages of the BRICS are made up of sovereign wealth funds and gold and foreign exchange reserves within the boundaries of the existing WSC. So, the refusal of the BRICS to use the international currencies such as the dollar and the euro will mean the loss of their competitive advantages.

Thus to take a more important position in the WSC, the BRICS have to export more capital and more goods and services; stimulate the process of their currencies' internationalisation; increase the use of these currencies in international, regional and sub-regional transactions and settlements and also in the border districts; provide loans to foreign countries in national currencies; improve monetary cooperation; and set up niches to trade in currency instruments denominated in the national currencies at the foreign exchange markets.

It is therefore important to turn now to analysing the general issues of the currency internationalisation and specific cases of the BRICS currencies' internationalisation.

The currency internationalisation is part of the financial globalisation and a good driver for the countries to integrate into the IFA and world capital markets that give wide access to liquid assets. On that basis the author concludes that the currency internationalisation significantly benefits the issuer country as follows:

a) It has the possibility of making use of seigniorage, i.e. it receives revenue as a result of the issuance. According to some estimates, approximately $60 \%$ of the dollar supply circulate outside the US, and if an interest rate in the country equals to, say, $4 \%$, then the revenue from charging the interest rate will amount to about $0.1 \%$, or more than 17 billion dollars a year

b) It may finance the deficit of the payment balance and current-account deficit

c) It may receive the emission rent which means an increase in clientele for the national banking sector and getting a competitive advantage in the national currency's trading abroad, for this industry gets a privileged access to the funds of the issuance country's central bank and is able to create debt in the international currency

d) It may expect increasing demand on the part of non-residents for the banking and nonfinancial services expressed in an internationalised currency, including the services such as foreign exchange transactions and investor consulting. To this end the financial sector of the international currency's issuance country will support and sustain the development of the industrial sector, for then interest rates and the cost of capital in the economy will decrease and make real investments look more profitable a business

e) Its multinationals may benefit from internationalising the currency of the country of origin because their foreign exchange risk will be overloaded on to their foreign counterparts.

Since the financial globalisation is a factor of spreading the financial crises, then the currency internationalisation may also involve potential risks for the countries of issuance. These risks are:

a) More speculative capital inflows under the conditions of circulating any national currency and securities denominated in it abroad may destabilize the domestic currency system and the country of issuance

b) The lack of restrictions and legislation to use and circulate an international currency in foreign economic transactions does not allow to control and regulate the cross-border movement of capital

c) The issuance of government and private debt securities denominated in an international currency abroad may involve the significant growth of external government and private debt. Therefore, the issuer countries of the international currencies usually have serious negative positions in foreign assets and debt

d) Liberalizing capital transactions in absence of the flexible free-floating exchange rate regime leads to a situation where a fixed or tightly managed exchange rate of an international currency prevents automatic equalization and balancing capital's inflow and outflow

e) Lifting restrictions on capital movement without market principles as to setting interest rates in an issuer country of an international currency may make households withdraw their 
deposits from the banking sector, which will cause the liquidity crisis and will help develop shadow banking

f) A country issuing an international currency may face the loss of independence in domestic monetary and macroeconomic policies. As a rule, an issuer country of an international currency is expected to observe certain exchange rate regime, sustain its fluctuations within some hard bounds, set limits on changes of the rate of refinancing, etc. The issues of independent macroeconomic policy find themselves in the theory of optimal currency zones. According to this theory, the exchange rate is a stabilisation instrument which can be used to cover the current-account deficit.

Nevertheless, when considering various schemes of the BRICS going over to direct settlements in national currencies, the author has found that the conditions of the optimal currency zones may be unacceptable in a situation of refusing national currencies in favour of the common one in the mutual trade. According to the results of the research, the conclusions of the optimal currency zones' theory point out at a very small possibility that within the BRICS there will be a currency union with a common currency. That means it is more rational for them to keep independent currencies. And sometimes it is quite beneficial to use the dollar or the currency of the strongest and largest economy of the regional integration grouping when transacting with each other.

\section{The Results}

The analysis which has been carried out by the author shows that the internationalisation of the BRICS' currencies may be divided into four stages: micro, medium, macro and mega levels (Fig. 1).

For the micro level of the BRICS currencies' internationalisation, the major conclusions and outcomes of the optimal currency zone's theory are true in the case only when one of them is used as a common currency. The examples include rupee which is used as a common currency in Bhutan and Nepal within the SAARC and rand that is a common currency for Lesotho, Namibia and Swaziland which are the member states of the SACCU/Z. The rationality of keeping independent currencies by the member states of the integration groupings with the BRICS' participation is determined by a significant difference in the level of their economic development. And in case of a crisis, weak countries using a common currency will not be able to turn to conventional macroeconomic instruments such as exchange rate regulation, default on external government debt and currency devaluation to increase export competitiveness. Meanwhile, the BRICS currencies can be allowed to be used in circulation as units of account in the member states.

Medium-level internationalisation of the BRICS' currencies can proceed in near-border regions. Here the resident commercial banks of two countries (for example, China and Russia in the Far East) are given the right to open special accounts in the national currencies, particularly the rouble and the yuan, for companies and individuals to transact with each other in cross-border deals. Micro and medium level internationalisation of the BRICS' currencies is a stage on which a special foreign exchange infrastructure is being set up, first of all, a separate niche to trade in currency pairs of the national units of account.

On the basis of analysing the mutual trade within the integration blocs, we have found that the major mechanism of the currency internationalisation at the macro level is the establishment of the appropriate financial infrastructure including the creation of special niches at the foreign exchange markets to trade in the given currency. We have concluded that direct settlements in the BRICS' currencies will not bring a positive effect without the backing of trading in this currency at the foreign exchange markets of the regional integration groupings' member states. An incentive to make direct settlements happen may be beneficial and favourable conditions of purchasing the BRICS' currencies at the foreign exchange markets of the member states in compare to the conditions offered by their central banks.

We recommend therefore that the commercial exchange rates should be set separately for exports and imports in order to stabilize BRICS currencies exchange rates in the course of the internationalisation process, since the latter requires their free and unrestricted circulation when using the methods of government 
regulation (e.g. central bank's intervention) is out of the question. Indirect regulation may be exercised only by means of setting less favourable commercial exchange rates for foreign countries with which the BRICS have currentaccount deficits and a more favourable one for the foreign trade partners which are most attractive for the BRICS to trade and cooperate with.

For example, the rand's internationalisation is analysed at the level of SAACU/Z, which is a currency union without the common central bank and ultra-national currency. In South Africa, in addition to the monetary policy of setting the commercial exchange rate, there is a mechanism for fixing financial exchange rates to allow transactions with capital. We recommend, therefore, that the commercial and financial exchange rates of the national currencies should be used parallel to divide the foreign exchange market into a trade-oriented niche and a financially oriented one in order to prevent speculations. Such an approach may constitute one of the methods to internationalise the BRICS currencies in case of the government gradualist policies, meaning gradual liberalisation of transactions with capital and foreign exchange.

A very serious restraint on the rand's internationalisation is the domination of natural resources in the exports which are usually denominated in dollars. This is also true for the rouble and real. From this, you may draw a conclusion that if South Africa, Brazil and Russia continue to export raw materials in exchange for the dollars, it will be extremely difficult to increase the share of the national currencies' use in the foreign trade.

To this end in order to internationalise, say, the rouble at the macro level it is necessary to transform the Russian economy on a higher technological basis, diversify the structure of the industries, increase the use of the rouble in the transactions with the EEU to strengthen the competitive positions in contrast to China that is really active in it's penetrating the member states' markets, stimulate rouble-denominated direct and portfolio investment abroad and try to make the EU's countries accumulate roubles and rouble-denominated government bonds in their reserves. To make this happen the Rus- sian economy requires re-industrialization, the introduction of new technologies, attracting of foreign capital and an increase in the international competitiveness. Also, it is crucial to improving the rouble's purchasing power at the national, regional and international markets.

Major conditions for the BRICS currencies' internationalisation include free convertibility and free-floating exchange rate regime. To ensure the efficiency of this regime's performance in open economy conditions, a further and deeper development of the BRICS financial centres is needed that often involves diversifying the portfolio of foreign exchange market's instruments. The greatest share in the foreign exchange trading at the BRICS foreign exchange markets is taken by currency pair the dollar/ national currency. Therefore it is necessary to expand the supply of the currency instruments in which an obligatory condition would be to trade in currency pairs with the BRICS currencies' participation. In the case of the BRICS currencies' internationalisation, it is also very important to understand at which level and in which sequence their circulation and use abroad is occurring. For example, the macro level of the currency internationalisation precedes entering the international markets, whereas the micro and medium levels require a deeper integration of currencies within the regional agreements by means of creating special niches to trade in national currencies at the local or domestic foreign exchange markets.

To improve the mutual foreign trade transactions between Russia and China due to the high volatility of the rouble's exchange rate and under the current free-floating exchange rate regime, the instruments for hedging foreign exchange risks are required to ensure the stability and positive dynamics of exports and imports between both countries. According to the author, such instruments can be timely-optimal and type-optimal contracts to deliver the yuan at the Moscow Exchange. A timely-optimal contract is a currency vehicle to purchase the yuan at the Moscow Exchange at the most favourable moment or period. A type-optimal contract, in its turn, is usually a derivative to purchase the yuan at the Moscow Exchange that provides a choice between several types of swap currency vehicles to do that. 
The currency internationalisation at the mega-level is about creating a relevant infrastructure to help conclude foreign trade contracts in the BRICS' currencies. It can be done within an international financial centre or an offshore centre of some of the BRICS' currencies, e.g. the yuan, on the one hand, and commercial banks of continental China. For example, Hong Kong, Taiwan, Singapore, London and Luxembourg have become the yuan's offshore centres responsible for making possible Chinese foreign trade with overseas markets using a certain limited amount of the currency in the yuan as well as derivatives and international bonds denominated in the yuan. The leading position in the infrastructure to settle foreign trade deals and capital account transactions in the BRICS' currencies can be taken by the central clearing institutions such as the central banks and foreign exchange markets as well as accountable commercial banks which are allowed to open special accounts to conclude business contracts in one of the BRICS' currencies, with a coordinating centre - the BRICS Development Bank, for example, - as the supreme clearing establishment responsible for organising and controlling the movement of capital (Fig. 2).

The internationalisation of the BRICS' currencies at the mega-level is the uppermost phase of their territorial or horizontal expansion on to the foreign markets.

\section{Conclusions}

The problems and the prospects of the yuan as an international currency are first of all connected with its inclusion in the SDR basket. This is a crucial factor for the yuan's internationalization in its strive to go over to the mega-level. However, since the SDRs take a small share in the international liquidity, a decisive determinant in the future yuan's use in the WSC would be a deeper financial reform in China, including total convertibility, the development of the national market of government and corporate bonds, providing international investors with more opportunities to purchase stocks of Chinese enterprises, the establishment of free liquidity funds, further liberalisation and the abolishment of various restrictions for foreign investors to use the yuan as well as the creation of the common channels between the national gross transfer settlement system and the payment systems of the other BRICS.

One of the major instruments to internationalise the yuan at the mega-level is to increase its share in China's credits abroad, first of all in the developing countries. The purpose of such loans is providing access to minerals needed for the Chinese industry as well as building infrastructure helping to extract and transport them.

As for the rouble's internationalisation at the mega-level, it must be said that this process is closely connected with the establishment of the yuan's offshore centre in Moscow. According to the author's hypothesis among the BRICS' international financial centres, Moscow has the brightest prospects in creating one, for there is a niche to trade in the yuan at the Moscow Exchange. No other BRICS' country has such a niche. Favourable conditions to purchase the yuan at the Moscow Exchange can be secured by means of diversifying the portfolio of special currency vehicles. The author has found that the most suitable currency vehicles denominated in the yuan for Brazilian, Indian and South African international businesses would be swaps in the yuan at the Moscow Exchange, whereas for the Russian exporters and importers a better solution would be purchasing the yuan on the spot market at the Moscow Exchange. So in case of realising the potential of Moscow as a new yuan's offshore centre, the rouble has more chances to internationalise, for this currency is intrinsic to all currency vehicles in the yuan traded at the Moscow Exchange. The rouble's mega-level internationalisation can also be driven by the further development of the rouble's offshore centre in Shanghai where there is a spot vehicle to trade in the currency pair rouble/yuan at the Chinese Foreign Exchange Trading System. A factor preventing the rouble from taking a better position in Shanghai, though, is weak diversification of Russian exports to China and an insufficient share of innovative products in them. Finally, the establishment and further deeper development of the rouble offshore centre in Shanghai and the yuan offshore centre in Moscow could be a transition stage in the latter's becoming a more important regional and later international financial centre. 


\section{References}

Avdokušin, Y.F., Kovalenko, V.N. (2012). The prospects of Chinese yuan's internationalisation [Perspektivy internatsionalizacii kitaiskogo ûanâ]. Voprosy novoi ekonomiki, 2, 43-49.

Binder, A.I. (2013). Some acute aspects of transforming yuan into a world currency [Nekotorye aktual'nie aspekti transformacii ûanâ v mirovuû valûtu]. Den'gi i kredit, 11, 59-62.

Burlačkov, V.K. (2012). The reform of the world system of currencies and the use of economic invariant [Reforma mirovoi valûtnoi sistemy i ispol'zovanie èkonomičeskogo invatrianta]. Voprosy èkonomiki, 1, 151.

Butorina, O.V. (2011). The currency wars. Who will pay for overcoming the crisis? [Valûtnye voiny. Kto zaplatit za preodolenie krizisa?]. Rossiâ v global'noi politike, 1(9), 165-178.

Goldberg, L.S., Cédric, T. (2008). Vehicle currency use in international trade. Journal of International Economics, 2(76), 177-192.

Griesgraber, J.M. (2009). Reforms for major new roles of the International Monetary Fund? The IMF Post-G-20 summit. Global Governance, 15(2), 179.

Jordà, Ò., Schularick, M., Taylor, A.M. (2011). Financial crises, credit booms, and external imbalances: 140 years of lessons. IMF Economic Review, 59(2), 340-378.

Kadayan, H. (2014). Indian rupee's role as an international currency. Abhinav - National Monthly Refereed Journal In Commerce \& Management, 2(3), 35-43.

Kasekende, L., Brixova, Z., Ndikumana, L. (2010). Africa: Africa's counter-cyclical policy responses to the crisis. Journal of Globalization and Development, $1,1$.

Kaufman, G.G. (2001). Emerging economies and international financial centres. Review of Pacific Basin Financial Markets and Policies, 4(4), 365-377.

Lane, P.R., Milesi-Ferretti, G.M. (2011). The cross-country incidence of the global crisis. IMF Economic Review, 2011, 59(1), 77-110.

Schindler, M. (2009). Measuring financial integration: A new data set. IMF Staff Papers, 1(56), 222-238.

Wade, R. (2008). The first world debt crisis of 2007-2010 in global perspective. Challenge, 51(4), 23-54.

Yu, Y. (2014). How far can renminbi internationalization go? Asian Development Bank Institute's Working Paper, $461,9-15$.

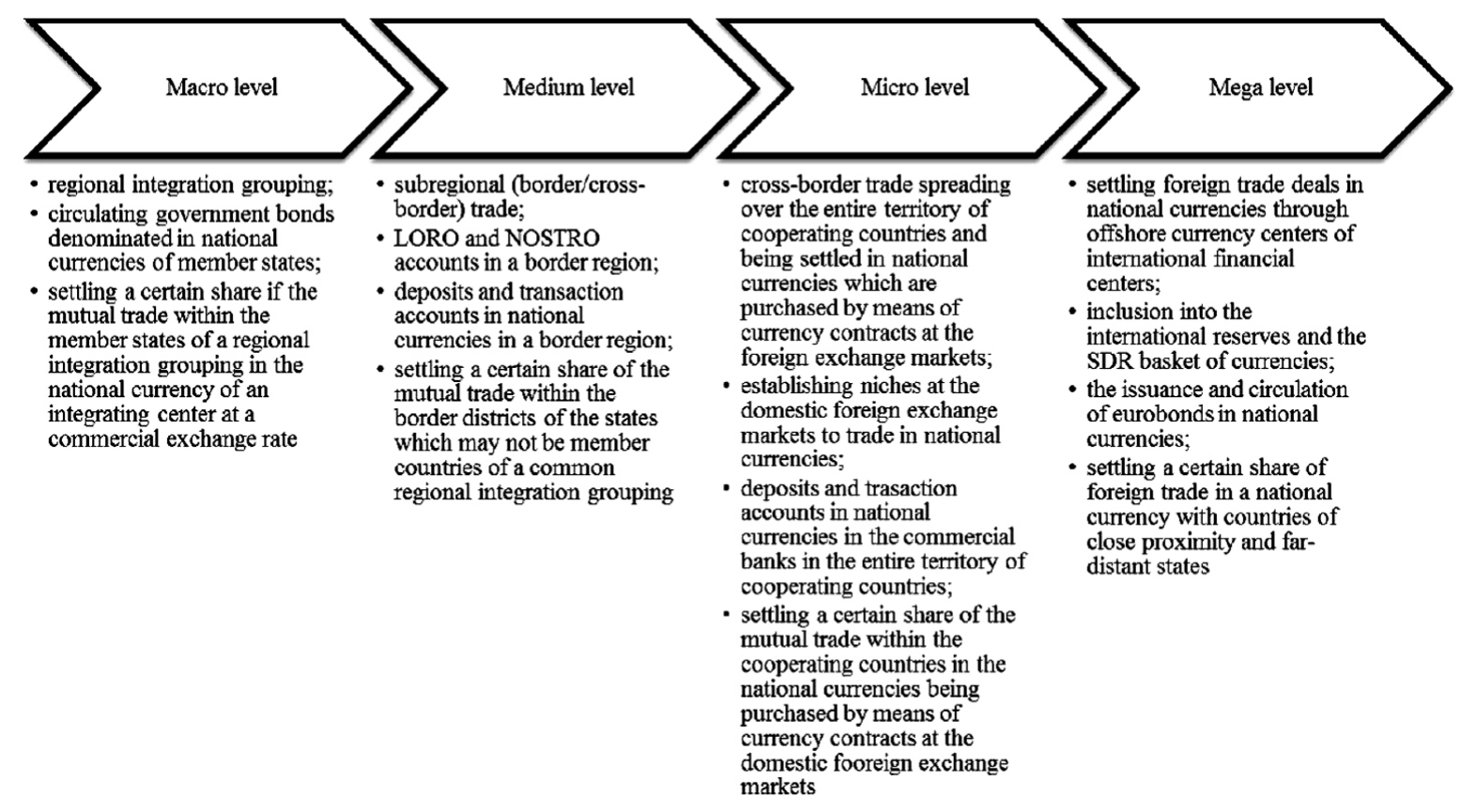

Figure 1. The multidimensional mechanism of the BRICS' currencies internationalisation.

Source: compiled by the author. 


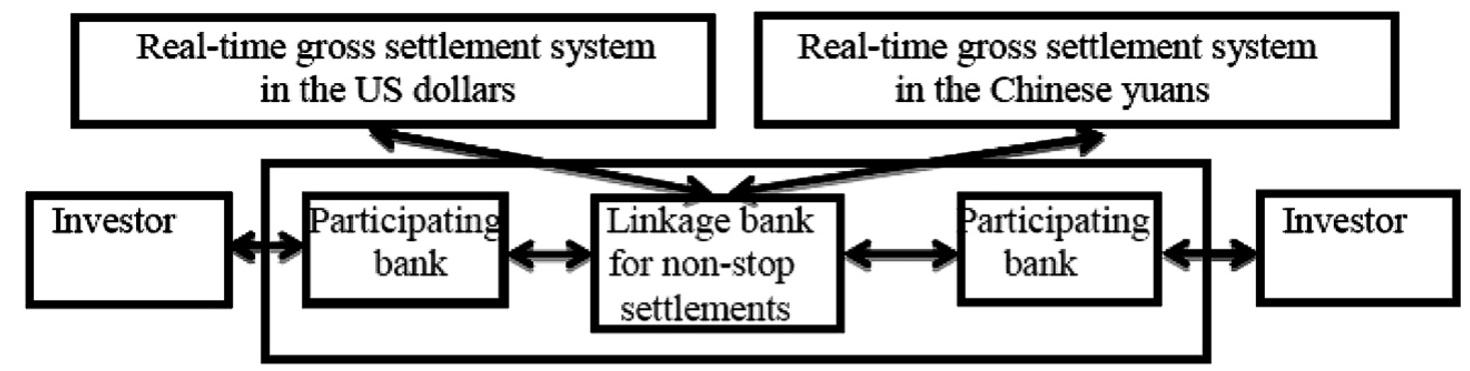

A bridge for carrying out settlements (payment-payment scheme)

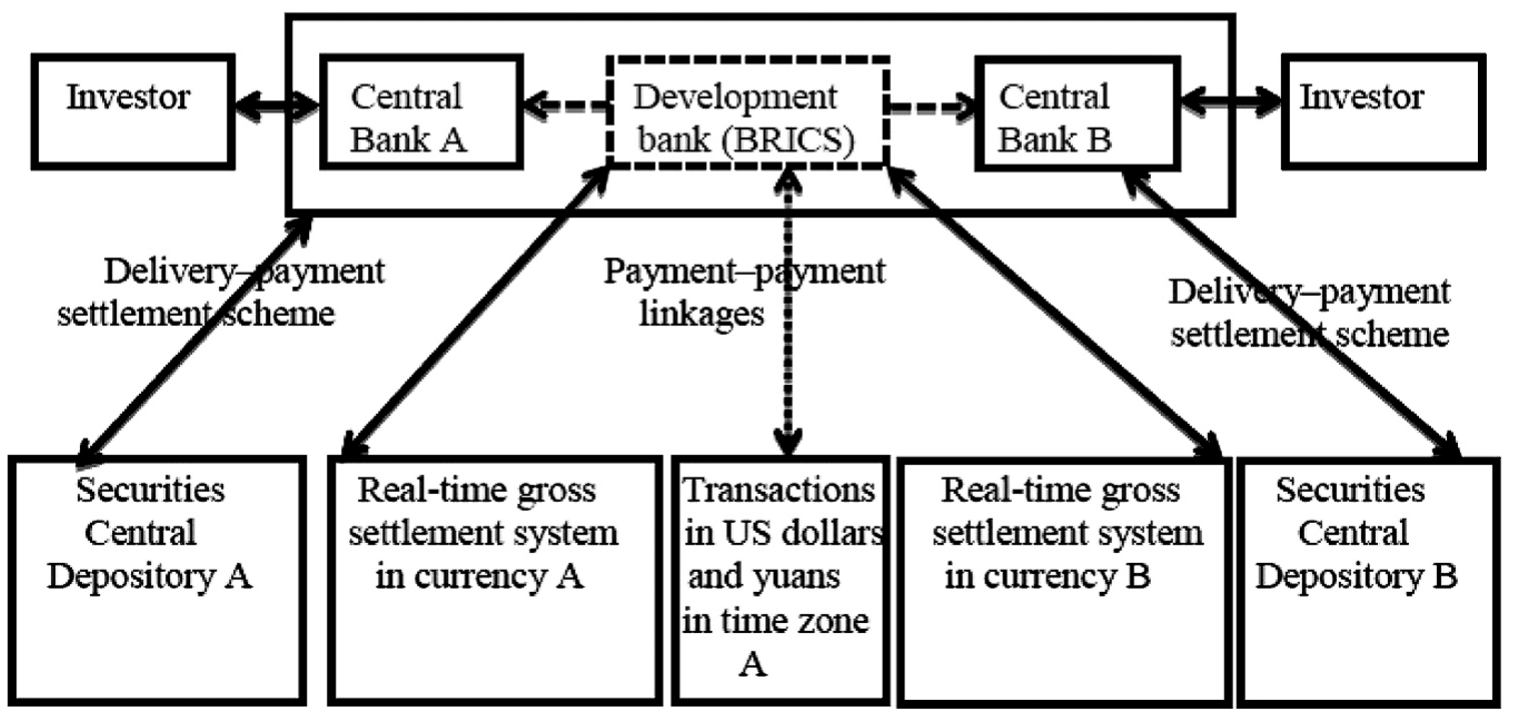

Figure 2. The mega-level internationalisation scheme of the BRICS' currencies.

Source: compiled by the author.

Инструменты реформы мировой валютной системы: интернационализация валют стран БРИКС

Михаил Жариков

Доктор экономических наук, профессор Департамента мировой экономики и мировых финансов, Финансовый университет, Москва, Россия

michaelzharikoff@gmail.com

http://orcid.org/0000-0002-2162-5056

Аннотация. Основные положения этой статьи исходят из гипотезы о том, что расширение использования валют стран БРИКС в современной мировой валютной системе (МВС) становится важнейшей движущей силой укрепления финансовой стабильности и трансформации МВС посредством процесса интернационализации, как результат организации прямых расчетов, а также с помощью их купли-продажи на базе валютных инструментов, обращающихся на валютных рынках. Вследствие этого возникает необходимость анализа обращения валют стран БРИКС за рубежом, выявления этапов и направлений их интернационализации с учетом роли, которую они могут играть в будущем развитии национальных экономик и приграничных территорий, сотрудничества во взаимной торговле, инвестиционных потоках, обмене технологиями, научных разработках, в сфере энергетики, финансовой стабильности и экономической безопасности. Проблематика статьи особенно актуальна в связи со становлением юаня как мировой резервной валюты, изменяющей структуру и функционирование МВС. Ключевые слова: валюты стран БРИКС; валютная интернационализация; финансовая глобализация; реформа международной финансовой архитектуры; мировая валютная система; режимы обменных валютных курсов стран БРИКС

JEL Classification: F37 